\title{
The Influence of Tax Planning and Tunneling Incentive on Transfer Pricing Decisions in Multinational Food and Beverage Companies Sub-Sector Listed on IDX from 2010-2018 Period
}

\author{
R. A. Sasqia Maharani Surbakti*, Eko Purwanto and Elok Faiqoh Himmah
}

Faculty Economic and Bussines, Universitas Informatika dan Bisnis Indonesia, Bandung, Indonesia *Corresponding author. Email: sasqiamaharani31@gmail.com

\begin{abstract}
This study aims to explore factors that influence the decision of companies to transfer prices to multinational companies in the food sub-sector with time measurements from 2010-2018. The variables in this study consisted of research variables consisting of Tax Planning and Tunneling Incentive as the independent variable and Transfer Pricing as the dependent variable. The population in this studies all manufacturing companies on the Indonesia Stock Exchange for the period 2010-2018. This study uses secondary data in the form of financial reports obtained from the official website of the Indonesia Stock Exchange, with a total sample of 6 companies taken according to the research criteria determined by the purposive sampling method. The data testing technique is done by using the classical assumption test, multiple regression coefficient test, determination coefficient test, correlation coefficient test, and hypothesis testing. The research results show that: 1) the tax variable has a significant effect on the company's decision to practice transfer pricing; 2) the tunneling incentive variable has a significant effect on the company's decision to practice transfer pricing; 3 ) Simultaneously, tax and tunneling incentives have a significant effect on Transfer Pricing at the Food and Beverage subsector Multinational companies listed on the Indonesia Stock Exchange from period 2010-2018.
\end{abstract}

Keywords: Transfer Pricing, Tunnelling Incentive, Tax Planning

\section{INTRODUCTION}

Economic globalization has influenced the progress of a country's economy. Economic globalization is any form of economic activity that shows market integration between countries without the constraints of territorial boundaries within a country. Economic globalization makes countries dependent on one another without losing the identity of each country [1]. The rapid development of globalization that occurs in the world of economy and business has led to an increasingly rapid economic development that recognizes no boundaries between countries.

Globalization in the business world has led to changes indirectly encouraging the spread of conglomeration and corporate visualization and the impact of increasing transnational transactions on cross-border transactions. Not to mention the presence of the World Trade Organization (WTO) which facilitates transnational trade which leads the world to a more complex cooperation arrangement. With the existence of this conglomerate business, we are acquainted with various names of wellknown corporate groups that have penetrated the business world nationally, regionally and internationally (multinational corporations).

Multinational companies in Indonesia are dominated by the food and beverage sub-sector. The food and beverage industry has an important role in economic growth in Indonesia. The food and beverage industry is projected to remain one of the mainstay sectors that support manufacturing growth and the national economy in the current era.

The rapid number of food and beverage industry causes this sector to contribute significantly to the GDP of Indonesia. The value of the food and beverage industry shows an increasing trend from 2014 to 2018. In 2014 the value of the food industry has reached 117 trillion rupiah and in 2018 it has increased to and reached 165 trillion rupiah. 
The data shows that from 2014 the first semester that the food and beverage industry dominates GDP revenue compared to other industries, namely IDR 117 trillion, while for other industries it shows an average percentage level of below IDR 50 trillion. The food and beverage industry developed rapidly into the following years. Until the end of 2017, the food and beverage industry contributed to reaching 165 trillion rupiah. Based on the data above, it can be said that the food and beverage subsector industry contributes greatly to national economic growth and contributes greatly to tax revenue.

Taxes is peoples contributions to the state treasury based on law without receiving compensation for lead services (counter-achievement) which can be shown directly and used to pay for general expenses [2]. Meanwhile, according to the Law of the Republic of Indonesia Number 16 of 2009 concerning General Provisions and Procedures for Taxation Article 1 paragraph (1): 8 Taxes are mandatory contributions to the State that are owed by private persons or entities that are compelling under the Law, without receiving compensation in directly and used for needs of the state for the greatest affluence of people.

Based on a report made by Ernesto Crivelly, from IMF investigators in 2016, which has been reviewed by the UN University using the database of the International Center for Policy and Research (ICTD), and the International Center for Taxation and Development (ICTD), it shows that there is tax avoidance being carried out entrepreneurs from 30 countries.

Indonesia is ranked 11th and the amount of corporate tax avoidance is insignificant compared to other countries. However, considering that Indonesia is a developing country with $70 \%$ income from the tax sector, this is a material thing for the source of state income [3].

Quoting from the page of the Directorate General of Taxes, it is stated that as many as 2,000 multinational companies operating in Indonesia do not pay Corporate Income Tax (PPh) Article 25 and Article 29 due to reasons of loss. These foreign companies use three main modes in order to get rid of taxes in Indonesia. Then as many as 2,000 companies consist of companies in the trade sector, and so on.

Transfer pricing often experiences problems in the aspect of tax abuse, because this activity involves customs matters, anti-dumping provisions, changes in income transfer, and changes in tax base (tax base) from one taxpayer to another. This transaction can result in a transfer of income, tax base or fees from one taxpayer to another taxpayer which can be manipulated to reduce the total amount of tax owed to taxpayers who have this special relationship [4]. Transfer pricing can be said to be successful from a tax perspective due to a special relationship, if one party has the ability to control another party or has significant influence over the other party in making financial and operational decisions [5]. Given the effects of a special relationship with a party, PSAK 7 requires the disclosure of certain information from related parties. This practice is known as tax avoidance by increasing the purchase price and reducing the selling price between companies in one group and transferring profits to companies operating in countries that apply low tax rates [6].

Tax management aims to fulfill tax obligations as best as possible in accordance with existing regulations and for the efficiency of tax obligations to achieve proper profit and liquidity [7]. Ownership structure in Indonesia is concentrated on a few owners, resulting in agency conflicts between major shareholders and minority shareholders. Tunneling Incentive is an incentive obtained from the transfer of company assets and profits by the majority shareholder but minority shareholders bear the consequences. The corporate governance system has an implementation mechanism which is often limited to following the stipulations of rules, without applying the benefits and awareness of the importance of corporate governance. Country governance mechanisms are also influenced by corporate governance.

In Indonesia, the average company has a concentrated ownership structure, this is an opportunity for Tunneling Incentive to occur. Tunneling incentives are the motivation for transfer pricing because the majority shareholder can transfer the company's assets or profits by conducting Transfer Pricing for their own benefit [9] It can be said that the company will do things that make the tax costs small [10].

Based on research on ref [11], it is stated that taxes have an effect on the application of transfer pricing. However, states that taxes have an effect on transfer pricing decisions. which states that tunneling incentives affect transfer pricing decisions. However, research on ref [12], states that tunneling incentives have no influence on the company's decision to carry out transfer pricing.

\section{METHODOLOGY}

This research uses quantitative research methods. "The quantitative method can be interpreted as a research method based on a post positivist philosophy, used to research on certain populations or samples, data collection using research instruments, quantitative or statistical data analysis, with the aim of testing predetermined hypotheses [13]. The research variables consisted of Tax Planning and Tunneling Incentive as the independent variable and Transfer Pricing as the dependent variable.

The population in this study are all manufacturing on the Indonesia Stock Exchange (BEI) from 2010-2018. Research sample determined by purposive the sampling method. Following are the criteria and the number of samples determined by the purposive sampling method and then used in the study.

The data collection technique is carried out by the author with documentation, namely the collection of data in the form of annual financial reports in the Food and Beverage Sub-Sector Manufacturing Companies listed on the Indonesia Stock Exchange 2010-2018 (www.idx.co.id). The data testing technique is carried out 
by a series of tests, namely the classical assumption test, multiple regression test, correlation coefficient test, and hypothesis testing (See Table 1).

Table 1 Determination of Sample Criteria

\begin{tabular}{|c|c|c|}
\hline No & Criteria & Total \\
\hline 1 & $\begin{array}{l}\text { Food and beverage sub-consumer goods } \\
\text { industry sector who listed in the Indonesia } \\
\text { Stock Exchange. }\end{array}$ & 31 \\
\hline 2 & $\begin{array}{l}\text { Manufacturing companies food and } \\
\text { beverage sub-consumer goods industry } \\
\text { sector that were not listed consecutively } \\
\text { on the Indonesia Stock Exchange from } \\
\text { 2010-2018 period. }\end{array}$ & -17 \\
\hline 3 & $\begin{array}{l}\text { Food and beverage sub-sector companies } \\
\text { that do not publish their Financial } \\
\text { Statements to the Indonesia Stock } \\
\text { Exchange successively in the period } \\
\text { 2010-2018. }\end{array}$ & -4 \\
\hline 4 & $\begin{array}{l}\text { Food and beverage companies that are not } \\
\text { controlled by foreign companies with } \\
\text { ownership percentage of more than } 20 \% \\
\text { during the } 2010-2018 \text { period. }\end{array}$ & -4 \\
\hline 5 & $\begin{array}{l}\text { Companies that have the criteria } \\
\text { mentioned. }\end{array}$ & 6 \\
\hline
\end{tabular}

\subsection{Multiple Linear Regression Coefficients}

Multiple linear regression tests are conducted measure whether the independent variable affects the dependent variable and how much influence the two variables are. The following is a regression model in this study

$$
\mathrm{Y}=\alpha+\beta 1 \mathrm{X} 1+\beta 2 \mathrm{X} 2+\mathrm{e}
$$

Information:

$\begin{array}{ll}\mathrm{Y} & \text { : Dependent Variable (Transfer Pricing) } \\ \alpha & : \text { Constant } \\ \beta & : \text { Coefficient } \\ \mathrm{X} 1 & : \text { Independent Variable (Tax Planning) } \\ \mathrm{X} 2 & \text { : Independent Variable (Tunneling Incentive) }\end{array}$

\subsection{Coefficient Correlation}

The correlation coefficient to determine how strong the relationship between the two independent variables and the dependent variable is calculated through multiple correlation. Multiple correlation analysis is used to determine the degree of relationship or the strength of the relationship between $\mathrm{X} 1$ and $\mathrm{X} 2$ and $\mathrm{Y}$ variables. The correlation used is multiple correlations.

\subsection{Coefficient of Determination}

The coefficient of determination (R2) in essence measures how far the model's ability to explain the variation in the independent variable. The coefficient of determination is between zero and one $(0<\mathrm{R} 2<1)$. The small value of $\mathrm{R} 2$ means that the ability of the independent variables to explain the variation in the dependent variable is very limited. A value close to one means that the independent variable provides almost all the information needed to predict the variation in the variable in information.

$$
\mathrm{KD}=\mathrm{r}_{2} \times 100 \%
$$

Information:

$$
\begin{aligned}
& \mathrm{KD}=\text { Coefficient of Determination } \\
& \mathrm{R}=\text { Dependent Correlation Coefficient }
\end{aligned}
$$

\subsection{Hypothesis test}

Testing this hypothesis is to make temporary conclusions to refute and / or justify the problem to be studied, as a vehicle for establishing the provisional conclusion then the null hypothesis and alternative hypothesis are determined. The design of this research hypothesis testing is to test whether there is an influence between the independent variables, namely tax inspection, tax collection and sanctions on the dependent variable, namely value added tax revenue. Hypothesis testing is done using the $\mathrm{T}$ test and test

F. Hypothesis testing with the $\mathrm{T}$ test shows the significance of the effect of one variable individually in explaining the dependent variable. Individual independent variables are said to have an influence on the dependent variable, if the variable has a significance value (sig) below 0.05 . As for the $\mathrm{F}$ test, the independent variable is declared to have an influence if the value of Fcount > Ftable.

\section{RESULTS}

The object of this research is multinational in the food and beverage sector who are listed on the Indonesia Stock Exchange from 2010-2018. This population uses secondary data in the form of financial reports obtained from the official website of the Indonesia Stock Exchange, namely www.idx.co.id, with a total sample of 6 companies taken according to the research criteria described. 
Table 2 Multiple Regression

\begin{tabular}{ccccccc}
\hline & Unstandardized Coefficients & & $\begin{array}{c}\text { Standardized } \\
\text { Coefficients Beta }\end{array}$ & T & Sig. \\
\hline \multirow{2}{*}{ Model } & & B & Std. & & & \\
& & Error & & 5.35 & 0 \\
& (Constant) & 0.165 & 0.031 & & 6.733 & 0 \\
& X1 & 0.069 & 0.01 & 0.632 & 3.05 & 0.004 \\
\hline
\end{tabular}

a. Dependent Variable

\subsection{Multiple Linear Regression Analysis}

The results of data processing are as presented in Table 2 , then the variable regression equation for the application of taxes and tunneling incentives can be formed to managerial performance as follows:

$$
\mathrm{Y}=0.165+0.069 \mathrm{X} 1+0.200 \mathrm{X} 2
$$

Based on the regression model, it can be explained:

1. If $\alpha=\mathrm{a}$ constant of 0.165 , it means that if the variable of tax application and tunneling incentives is zero, then Transfer Pricing will be worth 0.165 .

2. If the regression coefficient value of the tax application variable is 0.069 , it means that if the tax application variable has increased by (one) unit, then the dependent variable, namely the Transfer Pricing variable, will increase by 0.069 .

3. If the tunneling incentive variable regression coefficient value shows 0.200 , meaning that if the tunneling incentive variable has increased by (one) unit, the dependent variable, namely the Transfer Pricing variable, will increase by 0.200 .

The description above can be concluded that the greatest influence of the two variables $\mathrm{X}$ is the tunneling incentive variable which will affect an increase of 0.200 so that the higher the tunneling incentive in an organization, the higher the Transfer Pricing carried out by the organization.

\subsection{Correlation Test}

The correlation coefficient is to determine how strong the relationship between the two independent variables and the dependent variable is calculated through multiple correlations.
Table 3 Correlation Coefficient

\begin{tabular}{|c|c|c|c|c|}
\hline \multicolumn{5}{|c|}{ Correlations } \\
\hline & & $\times 1$ & $x 2$ & $\mathrm{Y}$ \\
\hline \multirow[t]{3}{*}{$\times 1$} & Pearson Correlation & 1 & .320 & .723 \\
\hline & Sig. (2-tailed) & &, 018 & .000 \\
\hline & $\mathrm{N}$ & 54 & 54 & 54 \\
\hline \multirow[t]{3}{*}{$\times 2$} & Pearson Correlation &, 320 & 1 & .489 \\
\hline & Sig. (2-tailed) &, 018 & &, 000 \\
\hline & $\mathrm{N}$ & 54 & 54 & 54 \\
\hline \multirow[t]{3}{*}{$Y$} & Pearson Correlation & .723 & ,489 & 1 \\
\hline & Sig. (2-tailed) &, 000 &, 000 & \\
\hline & $\mathrm{N}$ & 54 & 54 & 54 \\
\hline
\end{tabular}

The results of Table 3 show that Asp. Sig. F Change 0.00 $<0.05$ then correlates. Thus, the degree of relationship between the variable of tax application and transfer pricing is between 0.70 and 0.89 , which means that it has a very strong relationship. While the degree of relationship between tunneling incentive and transfer pricing variables is between $0.30-0.49$, which means that it has a moderate relationship.

\subsection{Determination Test}

After obtaining the value of the correlation coefficient which states that the application of taxes and tunneling incentives has an effect on transfer pricing, then the calculation of how much influence the variable application of taxes and tunneling incentives $(\mathrm{X})$ has on the Transfer Pricing variable (Y) using SPSS 26 software.

Table 4 Determination Test

\begin{tabular}{lcccc}
\hline Model & R & R Square & $\begin{array}{c}\text { Adjusted R } \\
\text { Square }\end{array}$ & $\begin{array}{c}\text { Std. Error of } \\
\text { the Estimate }\end{array}$ \\
\hline 1 & $.773^{\mathrm{a}}$ & .597 & .581 & .14006 \\
\hline
\end{tabular}


In Table 4, the correlation coefficient value of the application of taxes and tunneling incentives with Transfer Pricing is 0.773 ( $\mathrm{R}$ value). In addition to the correlation coefficient, the table above also presents the R-square value (0.597) which is known as the coefficient of determination(KD). The coefficient of determination of $59.7 \%$ indicates that the $59.7 \%$ increase in Transfer Pricing at Multinational Food Sector Companies Listed on the IDX for the 20102018 Period was due to the application of taxes and 1 tunneling incentives. While the rest, which is $40.3 \%$, is the influence of other factors outside the variable of tax implementation and tunneling incentives.

\subsection{Hypothesis Testing Results}

\subsubsection{T test}

If value is sig. $\mathrm{t}<$ significant level $(0.05)$, then the independent variable individually affects the dependent variable. Conversely, if the value is sig. $t>$ significant level (0.05), then the independent variable individually has no effect on the dependent variable. Furthermore, to prove whether the application of taxes and tunneling incentives to Transfer Pricing, a statistical hypothesis is tested as follows:

Ho: $\beta=0$ The application of taxes and tunneling incentives has no effect on Transfer Pricing in Sector Multinational Companies Foods that are listed on the IDX for the 2010-2018 period

Ha: $\beta \neq 0 \quad$ The application of taxes and tunneling incentives has an effect on Transfer Pricing at Food Sector Multinational Companies Listed on the IDX from 2010-2018

The test statistic used to test the hypothesis above is the $t$ test, the table value used as a critical value of 1.673 obtained from table $t$ at $\alpha=0.05$ for two-way testing. The test criteria used are as follows.

1. If the absolute value $t_{\text {count }}>t_{\text {table }}$ then $\mathrm{HO}$ is rejected (significant).

2. If the absolute value of $t_{\text {count }} \leq t_{\text {table }}$, then $\mathrm{HO}$ is not successfully rejected (not significant).
Table 5 T test

\begin{tabular}{cccccc}
\multicolumn{2}{c}{$\begin{array}{c}\text { Unstandardized } \\
\text { Coefficients }\end{array}$} & & $\begin{array}{c}\text { Standardized } \\
\text { Coefficients } \\
\text { Beta }\end{array}$ & $\mathrm{T}$ & Sig. \\
Model & B & $\begin{array}{c}\text { Std. } \\
\text { Error }\end{array}$ & & & \\
(Constant ) & 0.165 & 0.031 & & 5.35 & 0 \\
X1 & 0.069 & 0.01 & 0.632 & 6.733 & 0 \\
X2 & 0.2 & 0.066 & 0.286 & 3.05 & 0.004 \\
\hline
\end{tabular}

a. Dependent Variable: Y

The results of processing as presented in Table 4.10 can be seen that the tcount of the variable application of taxes and tunneling incentives is on average above 5,350 with a significance value of less than 0.05 . Because the value of the variable tcount of the application of taxes and tunneling incentives is greater than the value of $t$ table $(5,350)$, then at an error level of $5 \%$ it was decided to reject Ho so that $\mathrm{Ha}$ was accepted. Thus it can be concluded that there is a significant effect of the application of taxes and tunneling incentives on Transfer Pricing at Food Sector Multinational Companies Listed on the IDX for the 2010-2018 Period.

\subsubsection{F test}

To test the overall regression model obtained or the simultaneous effect of the application of taxes and tunneling incentives on Transfer Pricing, the test is carried out with the F test statistic, the statistical hypothesis tested is as follows:

Ho: $\beta_{1}=\beta_{2}=0$, there is no influence of the application of taxes and tunneling incentives $(\mathrm{X})$ and against Transfer Pricing (Y).

Ha: $\beta_{1}, \quad \beta_{2}=0$, There is the influence of the application of taxes and tunneling incentives $(\mathrm{X})$ and on Transfer Pricing (Y).

Table 6 Result of ANOVA

\begin{tabular}{lccccc}
\hline Model & $\begin{array}{c}\text { Sum of } \\
\text { Squares }\end{array}$ & df & $\begin{array}{c}\text { Mean } \\
\text { Square }\end{array}$ & F & Sig. \\
\hline Regression & 1.482 & 2 & 0.741 & 37.767 & $.000^{\mathrm{b}}$ \\
1 Residual & 1.001 & 51 & 0.02 & & \\
Total & 2.482 & 53 & & & \\
\hline
\end{tabular}

a.Dependent Variable: $\mathrm{Y}$

b. Predictors: (Constant), X2, X1 
In Table 6 , the $\mathrm{F}_{\text {count }}$ value is 37.767 with a significance value of 0.000 . From table $\mathrm{F}$ for degrees of freedom $d f_{1}=$ $k=3$ and $d f_{2}=n-k=54-3=51$, the value of $\mathrm{F}_{\text {table }}$ is 2.79 . The results obtained from the comparison of Fcount to $F_{\text {table }}$ are Fcount $>$ Ftable (37.76> 2.79), so at a 5\% error level it was decided to reject $\mathrm{H} 0$ so that Ha was accepted. Judging from the significance value $0.000<0.05$, it can be concluded that the test is significant. It is concluded that the independent variables, namely the simultaneous application of taxes and tunneling incentives, have a significant effect on Transfer Pricing at Multinational Food Sector Companies Listed on the IDX for the 20102018 Period.

\section{DISCUSSION}

\subsection{The Effect of Tax Application on Transfer Pricing}

Based on the results of the multiple regression coefficient test, the regression coefficient value of the variable application of tax was 0.069 , with a significance level of 0.000. This indicates the first hypothesis which states that the application of tax affects transfer pricing decisions. In the tax variable above shows the effect of transfer pricing transactions, where transfer pricing transactions can be carried out with affiliated companies outside the country by shifting the profits of companies that are in countries with high tax rates to countries with low tax rates.

The results in this study identified that the higher or the increase in the percentage of ETR, the greater the company's decision to practice Transfer Pricing with parties who have special relationships abroad. The more possibilities for companies to practice transfer pricing, the smaller the taxes that will be received in a country, resulting in lower tax payments globally.

\subsection{Effect of Tunneling Incentive on Transfer Pricing}

Based on the results of the multiple regression coefficient test, it shows a positive value of 0.200 significance level Tunneling incentive variable of $0.004<0.05$. This indicates the second hypothesis which states that tunneling incentives have an effect on Transfer Pricing decisions where if a company's Tunneling incentive is getting bigger, the greater the company's decision to do transfer pricing.

Companies with ownership that are concentrated on one party or one interest tend to have tunneling in them. Special relationship transactions are more commonly used because companies listed on the Indonesian stock exchange must distribute dividends to the parent company and other minority shareholders. Increased expropriation or expropriation of resources by controlling shareholders and minority shareholders, will result in lower cash dividends paid.

\subsection{The Effect of the Application of Taxes and Tunneling Incentives on Transfer Pricing}

Based on the results of the multiple regression coefficient test, it shows a positive value of 0.859 with a significance level of the tax and tunneling incentive variables of 0.000 $<0.05$. This indicates the third hypothesis which states that collectively there is an influence on transfer pricing decisions. This is in line with the hypothesis that taxes and tunneling incentives have an effect on transfer pricing decisions because tunneling is one of the behaviors of management or majority shareholders who transfer company assets related to their personal interests, but the transfer costs are borne by minority shareholders.

Such is the Transfer Pricing practice that can be carried out by a subsidiary by selling inventory to the parent company at a price far below the market price, this method can affect the income of the subsidiary company, and the income received is smaller than it should be.

\section{CONCLUSION}

This study aims to determine the effect of taxes, tunneling incentives on Transfer Pricing in multinational companies listed on the Indonesia Stock Exchange. Based on the research results that have been described in the previous chapter, the following conclusions can be obtained:

Tax variables and tunneling incentive variables significantly influence the company's decision to practice transfer pricing. This identifies that the higher or the increase in the ETR percentage, the greater the company's decision to carry out Transfer Pricing practices with parties who have special relations abroad with lower tax rates than Indonesia. The greater the share ownership owned by foreign shareholders, the greater the influence of foreign controlling shareholders in determining various decisions in determining various decisions in the company, including the policy for determining transfer pricing. The coefficient value shows $\mathrm{R}$-squared 0.597 , this figure will be converted into a percent, which means the percentage contribution of the influence of the independent variable to the dependent variable. So the tax and tunneling variables in this study explain $59.7 \%$ of the transfer pricing variable variations. While the rest, which is $40.3 \%$, is the influence of other factors outside the variable of tax implementation and tunneling incentives. 


\section{REFERENCES}

[1] Q. Li, R. Reuveny. Economic globalization and democracy: An empirical analysis. British journal of political science, 33 (1) (2003) 29-54. DOI: https://doi. org/10.1017/S0007123403000024

[2] A. Afrizal. Indonesian Tax Amnesty and Its Implications. European Journal of Business and Management, 10 (35) (2013) 37-68. DOI: http://dx.doi. org/10.2139/ssrn.3553310

[3] I. Isnawati, B. A. Hilendri, Z. Isnaini, L. T. Jumaidi. Analisis Kehilangan Penerimaan Negara di Sektor Pajak sebagai Konsekuensi dari Pengukuhan Besaran Kenaikan Ptkp (Studi Kasus pada Dirjen Pajak Nusa Tenggara). Jurnal Aplikasi Akuntansi, 2 (2) (2018) 76101. DOI: https://doi.org/10.29303/jaa.v2i2.24

[4] M. Alibasic, N. Vignjevic-Dordevic, N. Jevtic, S. Jevtic. Tax Authorities and Procedures-Effects on MNK -Transparency International Experience. Ekonomika, Journal for Economic Theory and Practice and Social Issues, 59 (2019), 93-100. DOI: https://doi.org/10.2200 4/ag.econ. 288644

[5] S. Brignall, S. Modell. An institutional perspective on performance measurement and management in the 'new public sector'. Management accounting research, 11 (3) (2000) 281-306. DOI: https://doi.org/ $10.1006 /$ mare. 2000.0136

[6] E. J. Bartelsman, R. M. Beetsma. Why pay more? Corporate tax avoidance through transfer pricing in OECD countries. Journal of public economics, 87 (910) (2003) 2225-2252. DOI: https://doi.org/10.1016/S0 047-2727(02)00018-X

[7] S. M. Chaudhry, A. Mullineux, N. Agarwal. Balancing the regulation and taxation of banking. International Review of Financial Analysis, 42 (2015) 38-52. DOI: https://doi.org/10.1016/j.irfa.2015.01.020

[8] J. Martínez-Ferrero, I. M. García-Sánchez. Coercive, normative and mimetic isomorphism as determinants of the voluntary assurance of sustainability reports. International Business Review, 26 (1) (2017) 102-118. DOI: https://doi.org/10.1016/j.i busrev.2016.05.009
[9] A. W. Lo, R. M. Wong, M. Firth. Tax, financial reporting, and tunneling incentives for income shifting: An empirical analysis of the transfer pricing behavior of Chinese-listed companies. Journal of the American Taxation Association, 32 (2) (2010) 1-26. DOI: https:// doi.org/10.2308/jata.2010.32.2.1

[10] S. B. Nielsen, P. Raimondos-Møller, G. Schjelderup. Company taxation and tax spillovers: Separate accounting versus formula apportionment. European Economic Review, 54 (1) (2010) 121-132. DOI : https://doi.org/10.1016/j.euroecorev.2009.06.005

[11] W. Winarso. Pengaruh Pajak dan Tunneling Incentive Terhadap Keputusan Transfer Pricing Pada Perusahaan Pertambangan yang terdaftar di Bursa Efek Indonesia (BEI) Periode 2012-2017. Jurnal Ilmiah Akuntansi dan Manajemen, 15(1) (2019) 49-59.

[12] A. Susanti, A. Firmansyah. Determinants of transfer pricing decisions in Indonesia manufacturing companies. Jurnal Akuntansi dan Auditing Indonesia, 2 2 (2) (2018) 81-93. DOI: https://doi.org/10.20885/jaai.v ol22.iss 2 .art 1

[13] R. K. Frels, A. J. Onwuegbuzie. Administering quantitative instruments with qualitative interviews: A mixed research approach. Journal of Counseling \& Development, 91 (2) (2013) 184-194. DOI: https://doi.o $\mathrm{rg} / 10.1002 / \mathrm{j} .1556-6676.2013 .00085 . \mathrm{x}$ 